\title{
SISTEM PAKAR PENYAKIT GINJAL BERBASIS WEB
}

\author{
Muhammad Ariq Hendry ${ }^{1}$, Farhan Rinsky Mulya ${ }^{2}$, M. Ikhsan Gumanof ${ }^{3}$, Dwiny Meidelfi ${ }^{4}$ \\ Teknologi Rekayasa Perangkat Lunak, Teknologi Informasi, Politeknik Negeri Padang ${ }^{1}$ \\ Email :muhammadariq360@gmail.com¹ ${ }^{1}$ itshansky@gmail.com² \\ develop.igumanof@gmail.com ${ }^{3}$, dwinymeidelfi@pnp.ac.id ${ }^{4}$
}

\begin{abstract}
ABSTRAK
Kita semua tahu bahwa Kesehatan merupakan hal yang penting dan mahal, untuk menjaga Kesehatan tubuh kita perlu memperhatikan organ-organ yang ada di dalam tubuh kita dan salah satunya adalah ginjal. Ginjal berfungsi untuk menyaring dan membuang racun pada darah. Masih banyak orang yang kurang peduli dengan Kesehatan ginjalnya karena Sebagian besar orang tidak mengeluarkan gejala apapun sampai penyakit ginjal memasuki stadium lanjut. Dunia medis terkini makin banyak menggunakan komputer untuk membantu diagnosis untuk pencegahan dan penanganan suatu penyakit. Salah satunya adalah penggunaan sistem pakar. Penelitian ini bertujuan untuk membuat sebuah sistem pakar yang akan digunakan untuk diagnosis penyakit ginjal secara mandiri tanpa harus ke rumah sakit dan juga bertujuan untuk menghindari kontak dengan orang lain di masa pandemi.
\end{abstract}

Kata Kunci : Penyakit Ginjal, Web, Sistem Pakar

\begin{abstract}
We all know that Health is important and expensive, to maintain the health of our bodies we need to take care of the organ in our body one of them is the kidney. The kidneys function to filter and remove toxins in the blood. There are still many people who don't care about their kidney health because most people do not have any symptoms until kidney disease enters an advanced stage. The medical world is increasingly using computers to assist diagnosis for prevention and treatment of a disease. One of them is the utilization of an expert system. This study aims to create an expert system that will be used to independently diagnose kidney disease without having to go to the hospital. and also aims to avoid contact with others during a pandemic.
\end{abstract}

Keywords : Kidney illness, Web, Expert System

\section{PENDAHULUAN}

Penyakit ginjal merupakan penyakit yang sering ditemui dan diderita oleh pria maupun wanita. Beberapa kebiasan buruk seperti jarang mengonsumsi air putih, sering mengonsumsi minuman alkohol, dan kurang berolahraga. Penyakit ini akan mudah terjadi apabila sistem daya tahan tubuh mulai berkurang dan menurun, sehingga memungkinkan bakteri atau mikroorganisme apa saja bisa masuk ke dalam tubuh. Penanganan penyakit ginjal dapat dilakukan dengan berkonsultasi oleh pakar spesialis penyakit dalam yang akan mendiagnosa dari gejala-gejala yang dirasakan oleh pasien secara cepat dan tepat. Namun, ada beberapa kendala diantaranya adalah pakar yang tidak ada di tempat, biaya yang cukup mahal, serta masih terbatas. Maka dibutuhkanlah sebuat sistem pakar yang bisa mendiagnosa penyakit ginjal ke dalam komputer untuk selanjutnya dapat dipahami oleh orang lain dalam menyelesaikan pendeteksi penyakit ginjal dengan memanfaatkan pengetahuan kepakaran. (Ginting, 2018) 
Kurangnya pengetahuan mengenai gejala awal dan fasilitas kesehatan terkait penyakit ginjal menyebabkan semakin meningkatnya angka kematian yang disebabkan oleh penyakit ginjal di Indonesia. Oleh karena itu, juga diperlukan suatu teknologi komputer untuk memudahkan mendiagnosa penyakit ginjal sehingga bisa diketahui dan bisa ditindaklanjuti segera.(Azhar et al., 2016) Penyakit ginjal ini biasanya menyerang apabila kita sudah dewasa ataupun sudah lanjut usia, apabila itu terjadi belum tentu pakar dapat membantu kita pada saat itu juga.(Sataloff et al., n.d.) Dengan menggunakan aplikasi- berbasis web, informasi dari suatu pakar akan mudah didapat oleh pengguna, tanpa harus datang pada seorang ahli/pakar yang ahli pada bidangnya, Sistem ini diharapkan mampu memberikan informasi yang optimal dengan timbal balik dari pengguna dan sistem. (Nurhadi, 2018)

Kemajuan teknologi komputer yang pesat dapat membantu kehidupan manusia bahkan di dalam bidang-bidang di luar disiplin ilmu komputer. Sistem pakar adalah merupakan salah satu cabang kecerdasan buatan yang mempelajari bagaimana meniru cara berpikir seorang pakar dalam menyelesaikan suatu permasalahan, membuat keputusan maupun mengambil kesimpulan sejumlah fakta. Dimana sistem pakar (expert system) merupakan suatu perangkat lunak komputer yang memiliki basis pengetahuan untuk domain tertentu dan menggunakan penalaran inferensi menyerupai seorang pakar dalam menyelesaikan masalah. Pada dasarnya sistem pakar ini bertujuan untuk membantu banyak orang dengan mengimplementasikan ilmu para pakar dan masih belum bisa menggantikan peran pakar.(Sulistyohati et al., 2008)

Dengan berbagai permasalahan yang ada, maka jurnal ini akan membahas bagaimana membangun suatu aplikasi sistem pakar sehingga dapat membantu masyarakat dalam melakukan pencegahan serta pengobatan sesegera mungkin.

\section{LANDASAN TEORI}

\subsection{Kecerdasan Buatan (Artificial Intelligence)}

Kecerdasan buatan atau Artificial Intelligence biasa disingkat (AI) dalam dalam Bahasa inggris. Kecerdasan buatan yang dimaksud adalah sebuah mesin yang mampu berfikir, memproses, dan mengolah informasi yang ada untuk dapat membuat sebuah keputusan.(Putri, M.Kom, 2017) Agar komputer dapat mengambil keputusan dengan baik seperti manusia maka komputer diberi pengetahuan dan kemampuan untuk berpikir. Kemampuan untuk belajar dan mengambil keputusan, mampu memahami pesan yang kontradiktif ataupun ambigu, mampu menanggapi dengan efektif dalam situasi apapun, dan menggunakan penalaran yang baik dalam memecahkan masalah serta menyelesaikannya dengan cepat dan efektif.

\subsection{Sistem Pakar}

Sistem Pakar merupakan salah satu cabang dari Artificial Intelligence (AI) yang memakai secara luas pengetahuan atau knowledge khusus dimana pengetahuan tersebut dimasukkan kedalam computer yang digunakan untuk menyelesaikan sebuah masalah pada tingkat manusia. Sistem Pakar terdiri dari dua bagian utama yaitu lingkungan pengembangan (development environment) dan lingkungan konsultasi (consultation environment). Lingkungan pengembang yang ada pada sistem pakar digunakan sebagai tempat untuk memasukkan pengetahuan kedalam sistem pakar, sedangkan lingkungan konsultasi digunakan pengguna yang bukan pakar untuk memperoleh pengetahuan dari sistem pakar.

\subsection{Metode Forward Chaining}

Metode ini merupakan salah satu metode utama dari reasoning. Metode ini bekerja dengan dimulai dari data yang tersedia dan menggunakan aturan-aturan inferensi yang ditentukan untuk 
mendapatkan data lain, dijalankan terus hingga data telah mencapai sasaran dan kesimpulan bisa didapatkan. (Akil, 2017)

\section{METODE PENELITIAN}

Metode yang digunakan dalam sistem pakar penyakit ginjal adalah :

(1) Identifikasi masalah.

Pada tahap ini analisa pengetahuan dasar mengenai penyakit ginjal dilakukan. Analisa akan berguna untuk perancangan sistem pakar penyakit ginjal berbasis website.

(2) Perancangan.

Perancangan yang dilakukan adalah pembuatan antar muka website, basis pengetahuan, basis data aplikasi.

\section{a) Tabel Pakar}

Tabel pakar adalah fakta - fakta yang didapatkan dari pakar, ilmu pengetahuan, pengalaman, dan penelitian dalam mengenal atau mengidentifikasi gejala penyakit ginjal. Berikut data - data yang telah dikumpulkan :

Tabel 1. Tabel Gejala

\begin{tabular}{|l|l|}
\hline \multicolumn{2}{|c|}{ Tabel Gejala } \\
\hline $\begin{array}{c}\text { Kode } \\
\text { Gejala }\end{array}$ & \multicolumn{1}{c|}{ Nama Gejala } \\
\hline G01 & Nyeri saat buang air kecil \\
\hline G02 & Sering buang air kecil \\
\hline G03 & Demam dan menggigil \\
\hline G04 & Nyeri pinggang \\
\hline G05 & Nyeri perut \\
\hline G06 & Urine keruh dan berbau busuk \\
\hline G07 & Urine berdarah \\
\hline G08 & Mual dan muntah \\
\hline G09 & Nyeri punggung \\
\hline G10 & Buang air kecil terasa panas \\
\hline G11 & $\begin{array}{l}\text { Buang air kecil sedikit atau anyang- } \\
\text { anyangan }\end{array}$ \\
\hline G12 & $\begin{array}{l}\text { Jumlah dan frekuensi } \\
\text { berkurang }\end{array}$ \\
\hline G13 & Pembengke \\
\hline G14 & Tubuh mudah Lelah \\
\hline G15 & Sesak napas \\
\hline G16 & Gangguan irama jantung \\
\hline G17 & Nyeri atau esensi tertekan di dada \\
\hline
\end{tabular}

Tabel Gejala

\begin{tabular}{|c|c|}
\hline $\begin{array}{l}\text { Kode } \\
\text { Gejala }\end{array}$ & Nama Gejala \\
\hline G18 & Napas berbau tak sedap \\
\hline G19 & $\begin{array}{l}\text { Muncul ruam atau rasa gatal di } \\
\text { kulit }\end{array}$ \\
\hline G20 & Nafsu makan menurun \\
\hline G21 & $\begin{array}{l}\text { Nyeri atau pembengkakan pada } \\
\text { sendi }\end{array}$ \\
\hline G22 & Tremor di tangan \\
\hline G23 & Kejang \\
\hline G24 & Koma \\
\hline G25 & Kehilangan nafsu makan \\
\hline G26 & Kulit gatal berkepanjangan \\
\hline $\mathrm{G} 27$ & $\begin{array}{l}\text { Penurunan berat badan atau malah } \\
\text { meningkat }\end{array}$ \\
\hline G28 & Sering buang air di malam hari \\
\hline G29 & $\begin{array}{l}\text { Pembengkakan pada mata kaki atau } \\
\text { tangan }\end{array}$ \\
\hline G30 & Tekanan darah tinggi \\
\hline G31 & Gangguan tidur \\
\hline G32 & Kram dan kejang otot \\
\hline G33 & Pucat \\
\hline G34 & Pusing \\
\hline G35 & Disfungsi ereksi (pria) \\
\hline G36 & Gangguan keseimbangan \\
\hline G37 & Sulit menelan \\
\hline G38 & Keringat berlebih atau berkurang \\
\hline G39 & Vagina kering \\
\hline G40 & Penurunan libido \\
\hline G41 & Sembelit atau diare atau bergantian \\
\hline G42 & $\begin{array}{l}\text { Gangguan berkemih, seperti } \\
\text { mengompol atau sulit buang air } \\
\text { kecil }\end{array}$ \\
\hline G43 & Penglihatan buram atau ganda \\
\hline G44 & Lumpuh pada salah satu sisi wajah \\
\hline G45 & Jantung berdebar \\
\hline G46 & Edema \\
\hline G47 & Urine berbusa \\
\hline G48 & Letih, lesu \\
\hline G49 & Nyeri panggul \\
\hline G50 & Nanah pada urine \\
\hline G51 & $\begin{array}{l}\text { Pembengkakan pada wajah dan } \\
\text { kaki }\end{array}$ \\
\hline G52 & $\begin{array}{l}\text { Benjolan atau bengkak di sekitar } \\
\text { punggung bawah dan pinggang }\end{array}$ \\
\hline G53 & Keringat banyak pada malam hari \\
\hline G54 & Kekurangan darah \\
\hline
\end{tabular}


Tabel 2. Tabel Penyakit

\begin{tabular}{|l|l|}
\multicolumn{2}{|c|}{ Tabel Penyakit } \\
\hline Kode Penyakit & Nama Penyakit \\
\hline P01 & Infeksi ginjal \\
\hline P02 & Batu ginjal \\
\hline P03 & Gagal ginjal akut \\
\hline P04 & Gagal ginjal kronis \\
\hline P05 & Neuropati diabetik \\
\hline P06 & Sindrom Nefrotik \\
\hline P07 & Sindrom Nefritik \\
\hline P08 & Kanker Ginjal \\
\hline
\end{tabular}

(3) Implementasi.

Metode yang digunakan dalam implementasi adalah Forward Chaining (pelacakan ke depan) untuk mendiagnosa penyakit ginjal berbasis website.

(4) Uji coba.

Uji coba dilakukan untuk mengetahui bagaimana sistem dapat menyimpulkan hasil diagnosa penyakit ginjal.

\section{HASIL DAN PEMBAHASAN}

\subsection{Rule pada pakar}

Aturan - aturan yang digunakan di system pakar ini dalam mengidentifikasi penyakit ginjal adalah sebagai berikut :

Tabel 3. Tabel Rule Pakar

\section{Tabel Rule Pakar}

\begin{tabular}{|l|l|}
\hline G01 & If Nyeri saat buang air kecil and \\
\hline G02 & Sering buang air kecil and \\
\hline G03 & Demam dan mengigil and \\
\hline G04 & Nyeri pinggang and \\
\hline G05 & Nyeri perut and \\
\hline G06 & Urine keruh dan berbau busuk and \\
\hline G07 & Urine berdarah and \\
\hline G08 & Mual dan muntah then \\
\hline P01 & Infeksi Ginjal \\
\hline & \\
\hline G04 & If Nyeri pinggang and \\
\hline G09 & Nyeri punggung and \\
\hline G05 & Nyeri perut and \\
\hline G10 & Buang air kecil terasa panas and \\
\hline G02 & Sering buang air kecil and \\
\hline G07 & Urine berdarah and \\
\hline G06 & Urine keruh dan berbau busuk and \\
\hline
\end{tabular}

\begin{tabular}{|l|l|}
\hline G11 & $\begin{array}{l}\text { Buang air kecil sedikit atau anyang- } \\
\text { anyangan and }\end{array}$ \\
\hline G08 & Mual dan muntah and \\
\hline G03 & Demam dan menggigil then \\
\hline P02 & Batu Ginjal \\
\hline & \multicolumn{2}{|c|}{} \\
\hline G12 & $\begin{array}{l}\text { If Jumlah dan frekuensi urine berkurang } \\
\text { and }\end{array}$ \\
\hline G13 & Pembengkakan pada tungkai and \\
\hline G14 & Tubuh mudah lelah and \\
\hline G15 & Sesak napas and \\
\hline G16 & Gangguan irama jantung and \\
\hline G17 & Nyeri atau esensi tertekan di dada and \\
\hline G18 & Napas berbau tak sedap and \\
\hline G19 & Muncul ruam atau rasa gatal dikulit and \\
\hline G20 & Nafsu makan menurun and \\
\hline G08 & Mual dan muntah and \\
\hline G03 & Demam dan mengigil and \\
\hline G05 & Nyeri perut and \\
\hline G09 & Nyeri punggung and \\
\hline G21 & Nyeri atau pembekakan pada sendi and \\
\hline G22 & Tremor di tangan and \\
\hline G23 & Kejang and \\
\hline G24 & Koma then \\
\hline P03 & Gagal Ginjal Akut \\
\hline & \multicolumn{2}{|l|}{} \\
\hline G08 & If Mual dan muntah and \\
\hline G25 & Kehilangan nafsu makan and \\
\hline G26 & Kulit gatal berkepanjangan and \\
\hline G27 & $\begin{array}{l}\text { Penurunan berat badan atau malah } \\
\text { meningkat and }\end{array}$ \\
\hline G28 & Sering buang air di malam hari and \\
\hline G07 & Urine berdarah and \\
\hline G29 & $\begin{array}{l}\text { Pembengkakan pada mata kaki atau } \\
\text { tangan and }\end{array}$ \\
\hline G17 & Nyeri atau esensi tertekan di dada and \\
\hline G30 & Tekanan darah tinggi and \\
\hline G31 & Gangguan tidur and \\
\hline G32 & Kram dan kejang otot and \\
\hline G33 & Pucat and \\
\hline G34 & Pusing and \\
\hline G35 & Disfungsi ereksi (pria) then \\
\hline P04 & Gagal Ginjal Kronis \\
\hline \multicolumn{2}{|c|}{} \\
\hline G36 & If Gangguan keseimbangan and \\
\hline G37 & Sulit menelan and \\
\hline G38 & Keringat berlebih atau berkurang and \\
\hline Gagina kering and \\
\hline
\end{tabular}




\begin{tabular}{|l|l|}
\hline G44 & Lumpuh pada salah satu sisi wajah and \\
\hline G45 & Jantung berdebar then \\
\hline P05 & Neuropati Diabetik \\
\hline \multicolumn{2}{|l|}{} \\
\hline G46 & If Edema and \\
\hline G47 & Urine berbusa and \\
\hline G48 & Letih, lesu and \\
\hline G08 & Mual dan muntah and \\
\hline G25 & Kehilangan nafsu makan and \\
\hline G27 & $\begin{array}{l}\text { Penurunan berat badan atau malah } \\
\text { meningkat then }\end{array}$ \\
\hline P06 & Sindrom Nefrotik \\
\hline \multicolumn{2}{|l|}{} \\
\hline G02 & If Sering buang air kecil and \\
\hline G10 & Buang air kecil terasa panas and \\
\hline G49 & Nyeri panggul and \\
\hline G06 & Urine keruh dan berbau busuk \\
\hline G07 & Urine berdarah and \\
\hline G50 & Nanah pada urine and \\
\hline G04 & Nyeri pinggang and \\
\hline G05 & Nyeri perut and \\
\hline G08 & Mual dan muntah and \\
\hline G03 & Demam dan menggigil and \\
\hline G30 & Tekanan darah tinggi and \\
\hline G51 & Pembengkakan pada wajah dan kaki then \\
\hline P07 & Sindrom Nefritik \\
\hline & \multicolumn{2}{|l|}{} \\
\hline G52 & $\begin{array}{l}\text { If Benjolan atau bengkak di sekitar } \\
\text { punggung bawah dan pinggang and }\end{array}$ \\
\hline G09 & Nyeri punggung and \\
\hline G04 & Nyeri pinggang and \\
\hline G03 & Demam dan mengigil and \\
\hline G53 & Keringat banyak pada malam hari and \\
\hline G27 & $\begin{array}{l}\text { Penurunan berat badan atau malah } \\
\text { meningkat and }\end{array}$ \\
\hline G25 & Kehilangan nafsu makan and \\
\hline G33 & Pucat and \\
\hline G48 & Letih, lesu and \\
\hline G14 & Tubuh mudah Lelah and \\
\hline G07 & Urine berdarah and \\
\hline G54 & Kekurangan darah then \\
\hline P08 & Kanker Ginjal \\
\hline
\end{tabular}

\begin{tabular}{|c|c|c|c|c|c|c|c|c|}
\hline G02 & $\begin{array}{l}\text { Sering } \\
\text { buang air } \\
\text { kecil }\end{array}$ & $\mathrm{X}$ & $\mathrm{X}$ & & & & $\mathrm{X}$ & \\
\hline G03 & $\begin{array}{l}\text { Demam } \\
\text { dan } \\
\text { menggigi } \\
1\end{array}$ & $X$ & $X$ & $\mathrm{X}$ & & & $X$ & $\mathrm{X}$ \\
\hline G04 & $\begin{array}{l}\text { Nyeri } \\
\text { pinggang }\end{array}$ & $\mathrm{X}$ & $\mathrm{X}$ & & & & $X$ & $\mathrm{X}$ \\
\hline G05 & $\begin{array}{l}\text { Nyeri } \\
\text { perut }\end{array}$ & $X$ & $X$ & $\mathrm{X}$ & & & $\mathrm{X}$ & \\
\hline G06 & $\begin{array}{l}\text { Urine } \\
\text { keruh dan } \\
\text { berbau } \\
\text { busuk }\end{array}$ & $\mathrm{X}$ & $X$ & & & & $\mathrm{X}$ & \\
\hline G07 & $\begin{array}{l}\text { Urine } \\
\text { berdarah }\end{array}$ & $\mathrm{X}$ & $\mathrm{X}$ & & $X$ & & $X$ & $X$ \\
\hline G08 & $\begin{array}{l}\text { Mual dan } \\
\text { muntah }\end{array}$ & $X$ & $\mathrm{X}$ & $\mathrm{X}$ & $X$ & $X$ & $\mathrm{X}$ & \\
\hline G09 & $\begin{array}{l}\text { Nyeri } \\
\text { punggun } \\
\mathrm{g}\end{array}$ & & $\mathrm{X}$ & $\mathrm{x}$ & & & & $X$ \\
\hline G10 & $\begin{array}{l}\text { Buang air } \\
\text { kecil } \\
\text { terasa } \\
\text { panas }\end{array}$ & & $X \mid$ & & & & $X$ & \\
\hline G11 & $\begin{array}{l}\text { Buang air } \\
\text { kecil } \\
\text { sedikit } \\
\text { atau } \\
\text { anyang- } \\
\text { anyangan }\end{array}$ & & $X$ & & & & & \\
\hline G12 & $\begin{array}{l}\text { Jumlah } \\
\text { dan } \\
\text { frekuensi } \\
\text { urine } \\
\text { berkuran } \\
\text { g }\end{array}$ & & & $\mathrm{X}$ & & & & \\
\hline G13 & $\begin{array}{l}\text { Pembeng } \\
\text { kakan } \\
\text { pada } \\
\text { tungkai }\end{array}$ & & & $\mathrm{X}$ & & & & \\
\hline G14 & $\begin{array}{l}\text { Tubuh } \\
\text { mudah } \\
\text { Lelah }\end{array}$ & & & $\mathrm{X}$ & & & & $\mathrm{X}$ \\
\hline G15 & $\begin{array}{l}\text { Sesak } \\
\text { napas }\end{array}$ & & & $\mathrm{X}$ & & & & \\
\hline G16 & $\begin{array}{l}\text { Ganggua } \\
\mathrm{n} \quad \text { irama } \\
\text { jantung }\end{array}$ & & & $\mathrm{X}$ & & & & \\
\hline G17 & $\begin{array}{l}\text { Nyeri } \\
\text { atau } \\
\text { esensi }\end{array}$ & & & $\mathrm{X}$ & $X$ & & & \\
\hline
\end{tabular}

Tabel 4. Rule Relasi Pakar

\begin{tabular}{|c|c|c|c|c|c|c|c|c|c|c|}
\hline $\begin{array}{l}\text { Kode } \\
\text { Gejala }\end{array}$ & $\begin{array}{l}\text { Nama } \\
\text { Gejala }\end{array}$ & \begin{tabular}{|l}
$\mathrm{P}$ \\
0 \\
1
\end{tabular} & 2 & $\begin{array}{l}\mathrm{P} \\
0 \\
3\end{array}$ & I & 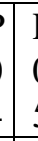 & & $\begin{array}{l}\mathrm{P} \\
0 \\
6\end{array}$ & $\begin{array}{l}\mathrm{P} \\
0 \\
7\end{array}$ & $\begin{array}{l}\mathrm{P} \\
0 \\
8\end{array}$ \\
\hline G01 & $\begin{array}{l}\text { Nyeri } \\
\text { saat } \\
\text { buang air } \\
\text { kecil }\end{array}$ & $X$ & & & & & & & & \\
\hline
\end{tabular}
esensi 


\begin{tabular}{|c|c|c|c|c|c|}
\hline & $\begin{array}{l}\text { tertekan } \\
\text { di dada }\end{array}$ & & & & \\
\hline G18 & $\begin{array}{l}\text { Napas } \\
\text { berbau } \\
\text { tak sedap }\end{array}$ & $\mathrm{X}$ & & & \\
\hline G19 & $\begin{array}{l}\text { Muncul } \\
\text { ruam atau } \\
\text { rasa gatal } \\
\text { di kulit }\end{array}$ & $X$ & & & \\
\hline G20 & $\begin{array}{l}\text { Nafsu } \\
\text { makan } \\
\text { menurun }\end{array}$ & $X$ & & & \\
\hline G21 & $\begin{array}{l}\text { Nyeri } \\
\text { atau } \\
\text { pembeng } \\
\text { kakan } \\
\text { pada } \\
\text { sendi }\end{array}$ & $X$ & & & \\
\hline G22 & $\begin{array}{l}\text { Tremor } \\
\text { di tangan }\end{array}$ & $X$ & & & \\
\hline G23 & Kejang & $X$ & & & \\
\hline G24 & Koma & $X$ & & & \\
\hline G25 & $\begin{array}{l}\text { Kehilang } \\
\text { an nafsu } \\
\text { makan }\end{array}$ & & $\mathrm{X}$ & $\mathrm{X}$ & \\
\hline G26 & $\begin{array}{l}\text { Kulit } \\
\text { gatal } \\
\text { berkepan } \\
\text { jangan }\end{array}$ & & $X$ & & \\
\hline G27 & $\begin{array}{l}\text { Penuruna } \\
\mathrm{n} \text { berat } \\
\text { badan } \\
\text { atau } \\
\text { malah } \\
\text { meningk } \\
\text { at }\end{array}$ & & $X$ & $X$ & \\
\hline G28 & $\begin{array}{l}\text { Sering } \\
\text { buang air } \\
\text { di malam } \\
\text { hari }\end{array}$ & & $X$ & & \\
\hline G29 & $\begin{array}{l}\text { Pembeng } \\
\text { kakan } \\
\text { pada } \\
\text { mata kaki } \\
\text { atau } \\
\text { tangan }\end{array}$ & & $X$ & & \\
\hline G30 & $\begin{array}{l}\text { Tekanan } \\
\text { darah } \\
\text { tinggi }\end{array}$ & & $\mathrm{X}$ & & $X$ \\
\hline G31 & $\begin{array}{l}\text { Ganggua } \\
\mathrm{n} \text { tidur }\end{array}$ & & $X$ & & \\
\hline G32 & $\begin{array}{l}\text { Kram dan } \\
\text { kejang } \\
\text { otot }\end{array}$ & & $X$ & & \\
\hline
\end{tabular}

\begin{tabular}{|c|c|c|c|c|c|}
\hline G33 & Pucat & $\mathrm{X}$ & & & $\mathrm{X}$ \\
\hline G34 & Pusing & $\mathrm{X}$ & & & \\
\hline G35 & $\begin{array}{l}\text { Disfungsi } \\
\text { ereksi } \\
\text { (pria) }\end{array}$ & $X$ & & & \\
\hline G36 & $\begin{array}{l}\text { Ganggua } \\
\mathrm{n} \\
\text { keseimba } \\
\text { ngan }\end{array}$ & & $\mathrm{X}$ & & \\
\hline G37 & $\begin{array}{l}\text { Sulit } \\
\text { menelan }\end{array}$ & & $X$ & & \\
\hline G38 & $\begin{array}{l}\text { Keringat } \\
\text { berlebih } \\
\text { atau } \\
\text { berkuran } \\
\mathrm{g}\end{array}$ & & $\mathrm{X}$ & & \\
\hline G39 & $\begin{array}{l}\text { Vagina } \\
\text { kering }\end{array}$ & & $X$ & & \\
\hline G40 & $\begin{array}{l}\text { Penuruna } \\
\text { n libido }\end{array}$ & & $\mathrm{X}$ & & \\
\hline G41 & $\begin{array}{l}\text { Sembelit } \\
\text { atau diare } \\
\text { atau } \\
\text { bergantia } \\
\mathrm{n}\end{array}$ & & $\mathrm{X}$ & & \\
\hline G42 & $\begin{array}{l}\text { Ganggua } \\
\mathrm{n} \\
\text { berkemih } \\
, \quad \text { seperti } \\
\text { mengom } \\
\text { pol atau } \\
\text { sulit } \\
\text { buang air } \\
\text { kecil }\end{array}$ & & $X$ & & \\
\hline G43 & $\begin{array}{l}\text { Penglihat } \\
\text { an buram } \\
\text { atau } \\
\text { ganda }\end{array}$ & & $\mathrm{X}$ & & \\
\hline G44 & $\begin{array}{l}\text { Lumpuh } \\
\text { pada } \\
\text { salah satu } \\
\text { sisi wajah }\end{array}$ & & $\mathrm{X}$ & & \\
\hline G45 & $\begin{array}{l}\text { Jantung } \\
\text { berdebar }\end{array}$ & & $\mathrm{X}$ & & \\
\hline G46 & Edema & & & $X$ & \\
\hline G47 & $\begin{array}{l}\text { Urine } \\
\text { berbusa }\end{array}$ & & & $X$ & \\
\hline G48 & $\begin{array}{l}\text { Letih, } \\
\text { lesu }\end{array}$ & & & $X$ & X \\
\hline G49 & $\begin{array}{l}\text { Nyeri } \\
\text { panggul }\end{array}$ & & & & \\
\hline G50 & $\begin{array}{l}\text { Nanah } \\
\text { pada } \\
\text { urine }\end{array}$ & & & & $\mathrm{K}$ \\
\hline
\end{tabular}




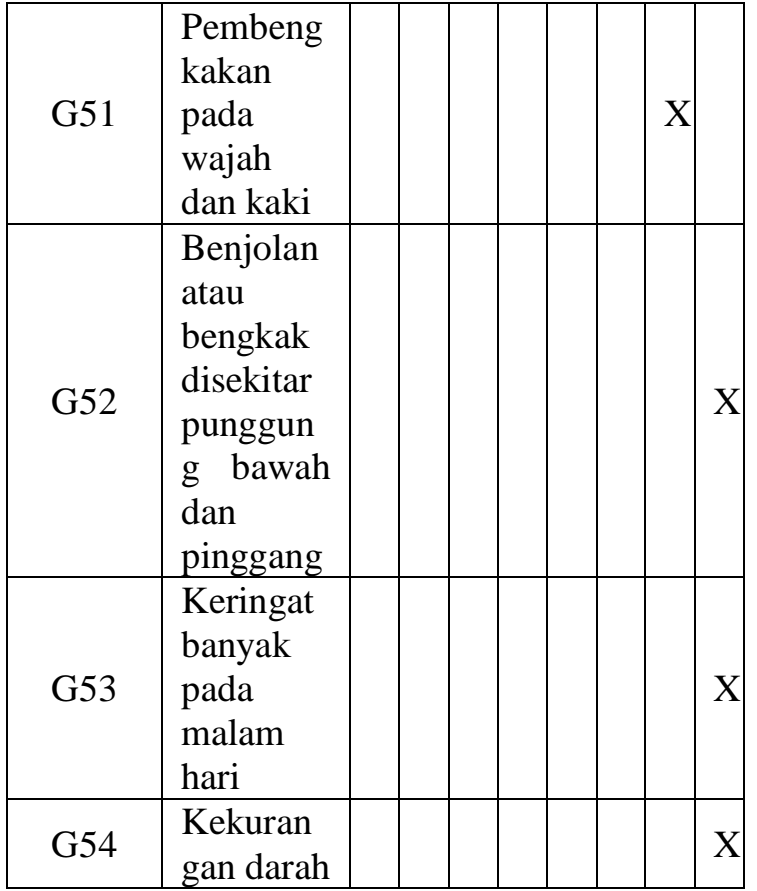

\subsection{Halaman Tampilan Web Sistem Pakar Penyakit Ginjal}

a. Halaman Login

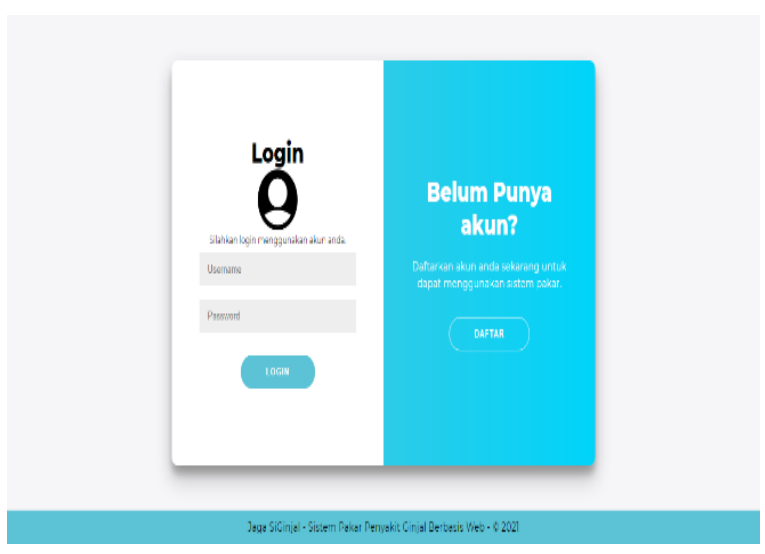

Gambar 1 Halaman Login

Agar dapat menggunakan sistem pakar user terlebih dahulu harus login menggunakan akun yang sudah terdaftar. Pertama isikan username pada kotak yang disediakan dan dilanjutkan dengan memasukkan password. Barulah klik button login untuk memverifikasi username dan password. Jika sukses maka user akan di kirim ke halaman utama. Jika user belum mempunyai akun maka klik button daftar.

\section{b. Halaman Daftar}

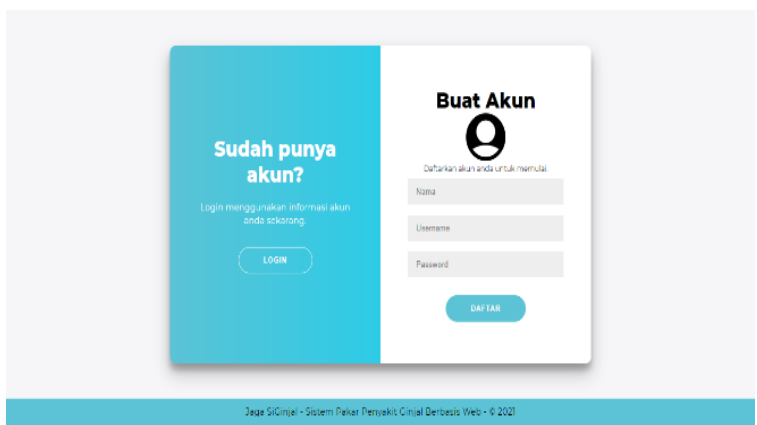

Gambar 2 Halaman Daftar

Pada halaman daftar user akan mengisikan data akun yang akan dibuat. Terdapat nama, username, dan password yang akan diinputkan user. Saat button daftar diklik data yang diinputkan user akan disimpan dan akun dapat digunakan.

\section{c. Halaman Utama}

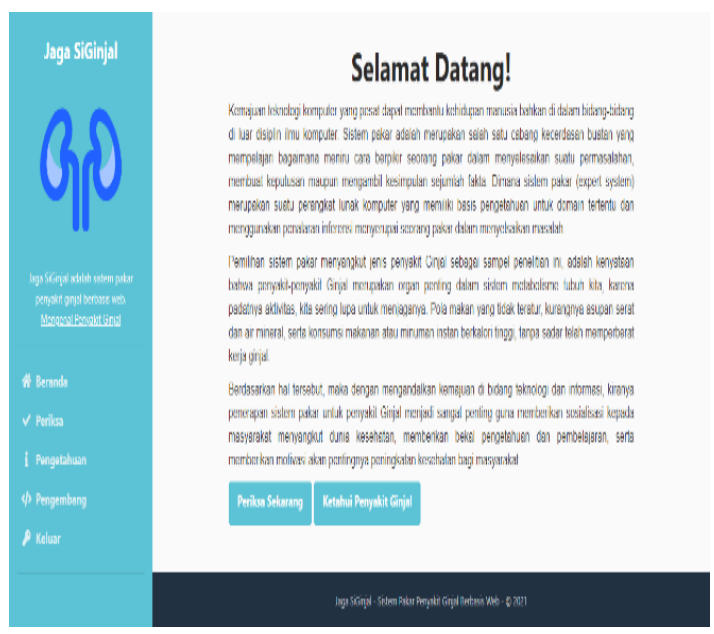

Gambar 3. Halaman Utama

Halaman utama berisi ringkasan singkat mengenai apa itu sistem pakar dan latar belakang pembuatan sistem pakar penyakit ginjal. Button periksa berfungsi untuk menjalankan pemeriksaan penyakit ginjal. Button ketahui penyakit ginjal berfungsi untuk menampilkan informasi mengenai penyakit ginjal. 


\section{d. Menu}

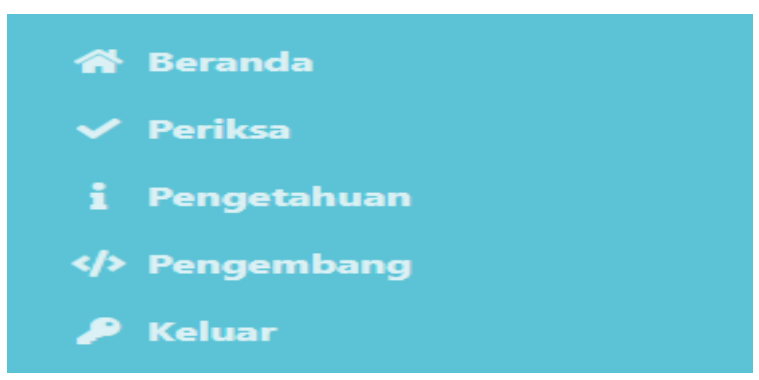

Gambar 4. Tampilan Menu

Terdapat 5 menu pada halaman website yaitu beranda, periksa, pengetahuan, pengembang, dan keluar. Menu beranda berfungsi menampilkan halaman utama website. Menu periksa berfungsi menjalankan pemeriksaan penyakit ginjal. Menu pengetahuan berfungsi menampilkan informasi penyakit ginjal. Menu pengembang menampilkan daftar pengembang website. Menu keluar berfungsi mengakhiri sesi user selanjutnya user akan dikirim ke halaman login.

\section{e. Halaman Periksa}
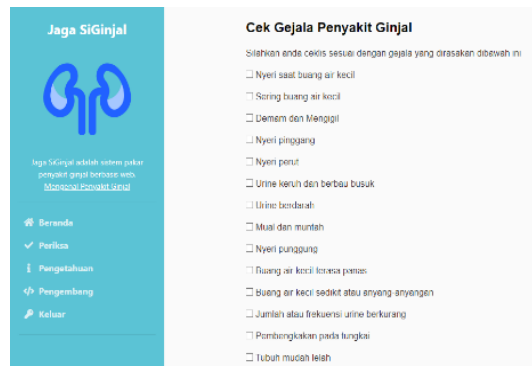

Gambar 5. Halaman Periksa

Halaman inilah dimana user akan menginputkan gejala-gejala penyakit ginjal yang dirasakan. User akan mencetang pilihan yang disediakan dan klik tombol kirim. Sistem akan memproses lalu menampilkan hasil yang sesuai dengan input user.

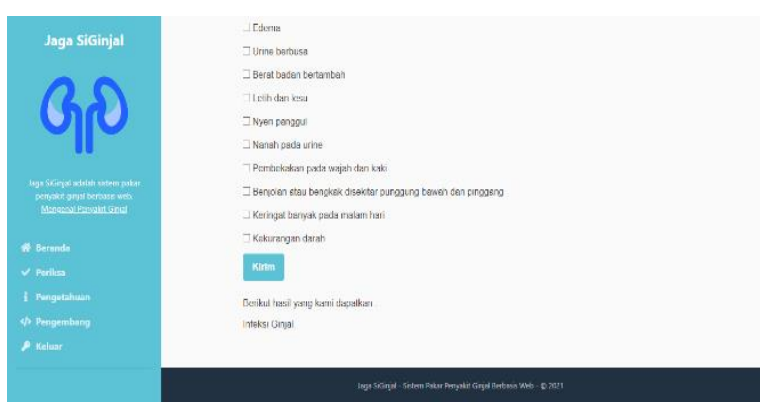

Gambar 6. Hasil Sukses

Hasil input user jika sesuai dengan gejala penyakit ginjal yang ada.

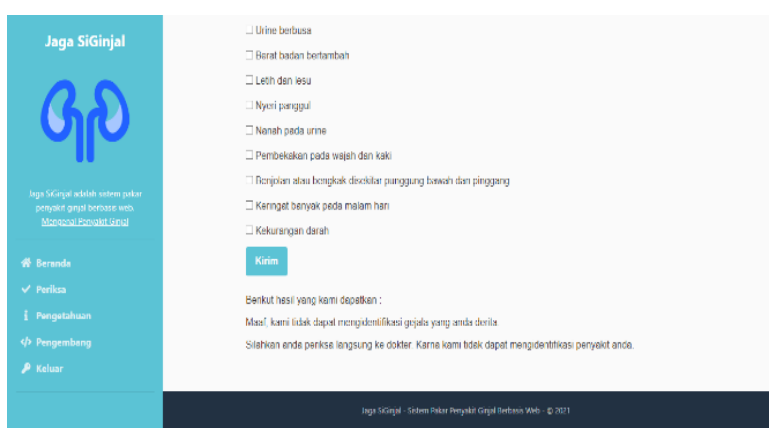

Gambar 7. Hasil Tidak Diketahui

Jika sistem tidak dapat menentukan hasil yang sesuai dengan input user maka akan menampilkan gambar diatas.

\section{f. Halaman Pengetahuan}
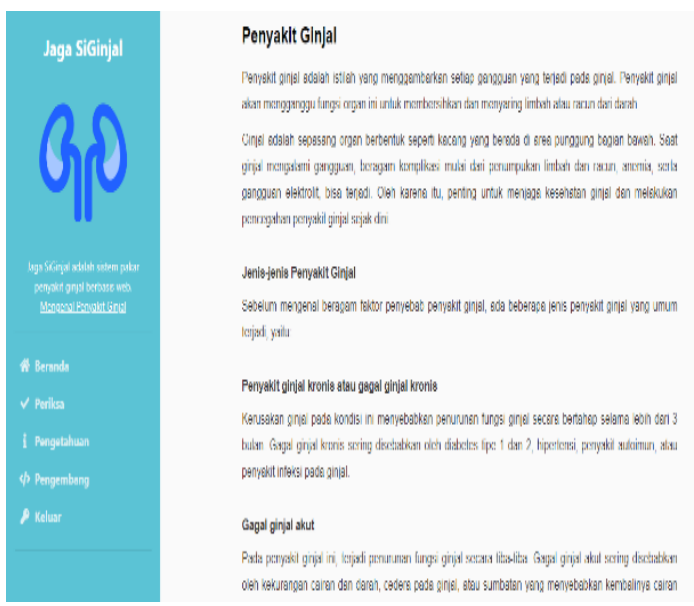

Gambar 8 Halaman Pengetahuan

Halaman pengetahuan berisi informasi seputar penyakit ginjal seperti jenis dan gejala penyakit. Terdapat juga cara mengobati dan pencegahan penyakit ginjal. 
g. Halaman Pengembang

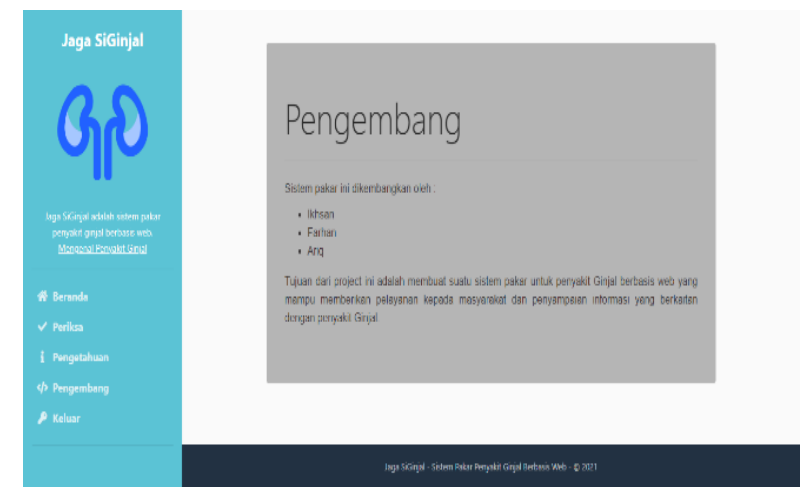

Gambar 9 Halaman Pengembang

Daftar pengembang dan tujuan pengembangan website sistem pakar.

\section{SIMPULAN DAN SARAN}

\subsection{Kesimpulan}

Berdasarkan hasil penelitian dan pembahasan tentang sistem pakar penyakit ginjal tersebut maka didapatkan kesimpulan bahwa sistem ini dapat membantu dalam mendiagnosis gejala gejala awal penyakit ginjal namun ada baiknya untuk konsultasi lebih lanjut ke dokter. Kita dapat memeriksa dimana saja dan kapan saja tanpa perlu membuat janji atau mengantri oleh karena itu sistem pakar ini juga dapat menghemat waktu untuk mendapatkan informasi tersebut.

\subsection{Saran}

a) Sebaiknya sistem ini dapat digunakan di berbagai fasilitas kesehatan dan bermanfaat bagi pengguna.

b) Sebaiknya tampilan dan pengoperasian sistem ini dibuat lebih sederhana.

c) Sebaiknya sistem ini dapat dikembangkan ke taraf yang lebih baik lagi sehingga bukan hanya digunakan untuk mendiagnosa penyakit ginjal pada manusia saja dan dapat berfungsi dengan luas .

\section{DAFTAR PUSTAKA}

Akil, I. (2017). Analisa Efektifitas Metode Forward Chaining Dan. Jurnal Pilar Nusa Mandiri, 13(1), 35-42.

Azhar, S., Sari, H. L., \& Zulita, L. N. (2016). Sistem Pakar Penyakit Ginjal Pada Manusia Menggunakan Metode Forward Chaining. Jurnal Media Infotama, 10(1), 16-26.

Ginting, W. (2018). Sistem Pakar Mendiagnosa Penyakit Ginjal Menggunakan Metode Case Based Reasoning. Information System Development, 3(2), 120-125.

Nurhadi, A. (2018). Sistem Pakar Diagnosa Penyakit Kucing Berbasis Web Menggunakan Metode Forward Chaining. 10(2), 70-78.

Putri, M.Kom, A. D. (2017). Sistem Pakar Mendeteksi Tindak Pidana Cybercrime Menggunakan Metode Forward Chaining Berbasis Web Di Kota Batam. Edik Informatika, 3(2), 197-210.

https://doi.org/10.22202/ei.2017.v3i2. 2244

Sulistyohati, A., Hidayat, T., Kunci: Ginjal, K., Pakar, S., \& Dempster-Shafer, M. (2008). Aplikasi Sistem Pakar Diagnosa Penyakit Ginjal Dengan Metode Dempster-Shafer. Seminar Nasional Aplikasi Teknologi Informasi. 